\title{
The Connection Between Opioid Withdrawal and Takotsubo Cardiomyopathy: Case Reports of 'Opioid Octopus Heart'
}

\author{
Benjamin Hack ${ }^{1}$ (D), Solabomi Ojeniyi ${ }^{2}$, Yakov Mamzhi ${ }^{1}$, Adeeb G Bou-Saba ${ }^{2}$, Louis Saade ${ }^{2}$ \\ ${ }^{1}$ Georgetown University School of Medicine, ${ }^{2}$ Internal Medicine, MedStar Georgetown University Hospital \\ Keywords: Takotsubo cardiomyopathy, opioid withdrawal, hyperadrenergic state, stress cardiomyopathy, case report \\ https://doi.org/10.52504/001c.31500
}

\section{Georgetown Medical Review}

Vol. 5, Issue 1, 2021

\begin{abstract}
Introduction
Takotsubo Cardiomyopathy (TCM) is an incompletely understood diagnosis. The leading hypothesis of its pathogenesis is that a hyperadrenergic state leads to cardiotoxicity, which is supported by case findings. Withdrawal from opioids is one potential etiology of an excessive adrenergic response and, therefore, may precipitate TCM.
\end{abstract}

\section{Case Presentations}

Here, we present 2 cases of TCM in patients who chronically used opioids, both at the same institution within 1 month of each other. The first patient is a 68-year-old man who presented with a chronic obstructive pulmonary disease exacerbation and did not disclose his long-standing opioid use disorder. One day after admission, he was found to be in opioid withdrawal and, soon after, developed TCM. He was originally treated for non-ST elevation myocardial infarction and opioid withdrawal but decompensated. He was sent to the intensive care unit (ICU) to receive pressors and fluid resuscitation. He soon recovered and his cardiac function returned to baseline.

The second patient is a 33-year-old woman with opioid use disorder taking methadone who presented with lower extremity weakness, edema, and pain. She was diagnosed with infective endocarditis. While awaiting surgery and receiving antibiotics, she developed respiratory failure and was upgraded to the ICU. There was a lapse in her opioid treatment, and she subsequently developed TCM. She was treated with pressors and fluids in the ICU, and eventually recovered with reduced cardiac function at the time of discharge.

\section{Conclusions}

While clinical evidence indicated opioid withdrawal as the likely provoking factor for development of TCM in the first case, the second patient's symptoms from other clinical complications confounded the cause of her TCM. Twelve similar cases have been reported in the literature, suggesting that opioid withdrawal may be associated with development of TCM. Further quantitative research is required to establish this relationship. Our findings contribute to the theoretical pathophysiology of TCM and offer important considerations for clinical management of opioid withdrawal.

\section{Introduction}

Takotsubo cardiomyopathy (TCM) is a widely recognized diagnosis comprised of left ventricular ballooning and dyskinesia, accompanied by possible troponin release and electrocardiographic (EKG) changes. ${ }^{1}$ The injury is generally considered reversible with good prognosis and high survival rates. ${ }^{1}$ The prevalence of the condition is estimated to be between $1.0 \%$ and $2.5 \%$ of ST-segment elevation infarcts, and most cases have occurred in postmenopausal women. ${ }^{1}$ The first cases were described in 1991, and were originally mistaken for myocardial infarction due to similarities in clinical 
presentation and laboratory results. A lack of coronary occlusion definitively differentiated TCM, with characteristic echocardiographic findings supporting the diagnosis. ${ }^{2}$ Diagnostic criteria were later established by the Mayo Clinic, consisting of (1) characteristic ventricular ballooning and dyskinesia, (2) new EKG abnormalities, (3) elevated troponin level, and (4) lack of coronary occlusion, pheochromocytoma, or myocarditis. ${ }^{3}$ Note that symptoms are not included, likely given the nonspecific and highly variable symptoms of $\mathrm{TCM}^{3}$ With modern advances in ultrasound sensitivity and percutaneous coronary intervention, as well as an improved understanding of TCM, there is ample opportunity to differentiate this condition from a myocardial infarction or other cardiac insults.

The mechanism of injury in TCM is widely discussed, but still unknown. The most commonly supported theory is that a hyperadrenergic state induces the cardiomyopathy, as discussed by Roshanzamir and Showkathali. ${ }^{4}$ They concluded that catecholamine excess directly results in microvascular dysfunction through $\alpha-1$ overstimulation, while direct cardiotoxicity results from $\beta$-1-mediated intracellular calcium overload. ${ }^{4}$ This proposed mechanism has earned TCM colloquial designations such as "stress" or "broken heart" cardiomyopathy, which is consistent with the increase of catecholamine release in response to emotional stress.

Opioid withdrawal has long been recognized as a potentially hyperadrenergic state. ${ }^{5}$ Chronic opioid exposure has been demonstrated to cause a tonic inhibition of noradrenergic receptors; abrupt cessation leads to disinhibition of these cells particularly in the primary region of norepinephrine synthesis, the locus coeruleus. ${ }^{5}$ Recent treatments have taken advantage of this physiology to alleviate the sympathetic complications of withdrawal. The sympatholytic $\alpha-2$ agonists lofexidine and clonidine have been implicated as potential alternatives or adjuncts to long-acting opioids. ${ }^{6,7}$ Although this connection has led to considerations in the pharmacology of opioid withdrawal, to our knowledge, it has rarely been discussed in the context of cardiac complications such as TCM.

Within 1 month at MedStar Union Memorial Hospital in Baltimore, Maryland, 2 patients who chronically used opioids developed TCM when opioids were withheld. This prompted us to conduct a literature review of this association, only to find that an analysis of this connection was lacking. We present the cases and discuss the current literature on this subject.

\section{Case Presentations}

Informed patient consent was obtained from both patients prior to manuscript preparation. 


\section{Case 1}

A 68-year-old man with a history of chronic obstructive pulmonary disease, psoriasis, and decades-long untreated opioid use disorder presented to the emergency department (ED) with shortness of breath, increased work of breathing, and chest pain. His worsening symptoms from baseline and relief with albuterol and ipratropium/albuterol led to a diagnosis of chronic obstructive pulmonary disease (COPD) exacerbation. He was afebrile and saturating at $98 \%$ on room air, with a heart rate of 83 beats/min, respiratory rate of 22 breaths/min, and blood pressure of 141/92 mmHg. Laboratory findings were significant for negative troponin and elevation of normal troponin/pro-B-type natriuretic peptide level of $3364 \mathrm{ng} / \mathrm{L}$. He originally described heroin use 1 week prior and was not given any opioids in the ED. Results from subsequent urine toxicology were positive for opiates. He later acknowledged using heroin consistently at least every other day, including the day before presenting to the ED.

On the second day of admission, he began demonstrating symptoms of agitation and vomiting with a clinical opiate withdrawal score of 9 and started treatment with oxycodone, $10 \mathrm{mg}$. The next day, he started treatment with buprenorphine/naloxone, $10 \mathrm{mg}$. His chest pain worsened, and EKG results revealed frequent premature ventricular contractions. His troponin level increased to $0.824 \mathrm{ng} / \mathrm{mL}$ and later peaked at $8.9 \mathrm{ng} / \mathrm{mL}$. Management for non-ST elevation myocardial infarction was initiated, including aspirin, 325 mg; clopidogrel, and heparin drip. Coronary angiography revealed nonobstructive coronary artery disease, midcavitary stress induced TCM with an ejection fraction of $10 \%$ to $15 \%$, and left ventricle akinesis (Figure 1). He was treated for stress cardiomyopathy with milrinone and intravenous furosemide, but he decompensated with blood pressures in the 80s/40s and was upgraded to the intensive care unit (ICU). He started treatment with norepinephrine and given fluid resuscitation. He recovered within 3 days and was stepped down to acute care services (ACS), where milrinone treatment was stopped. His ejection fraction improved to $40 \%$ to $45 \%$, which was similar to his baseline level. He was discharged 9 days after his original presentation. His ejection fraction remained at $40 \%$ to $45 \%$ at a follow-up appointment the next month.

\section{Case 2}

A 33 year-old woman with a 4-year history of intravenous drug abuse receiving maintenance methadone, $60 \mathrm{mg}$, presented to the ED with 3 weeks of bilateral lower extremity pain, edema, and weakness. She was afebrile and saturating at $97 \%$ on room air with a heart rate of 93 beats $/ \mathrm{min}$, blood pressure of $96 /$ $63 \mathrm{mmHg}$, and respiratory rate of $14 \mathrm{breaths} / \mathrm{min}$. Initial clinical opiate withdrawal score was 4 based on her heart rate, diaphoresis, and restlessness. Blood cultures revealed she was in sepsis secondary to methicillin-resistant Staphylococcus aureus bacteremic cellulitis. Given the patient's history of drug abuse and bacteremia, an echocardiogram was performed, which demonstrated a $1.9 \times 1.8 \mathrm{~cm}$ mobile vegetation and ejection fraction of $35 \%$ to $40 \%$ with 

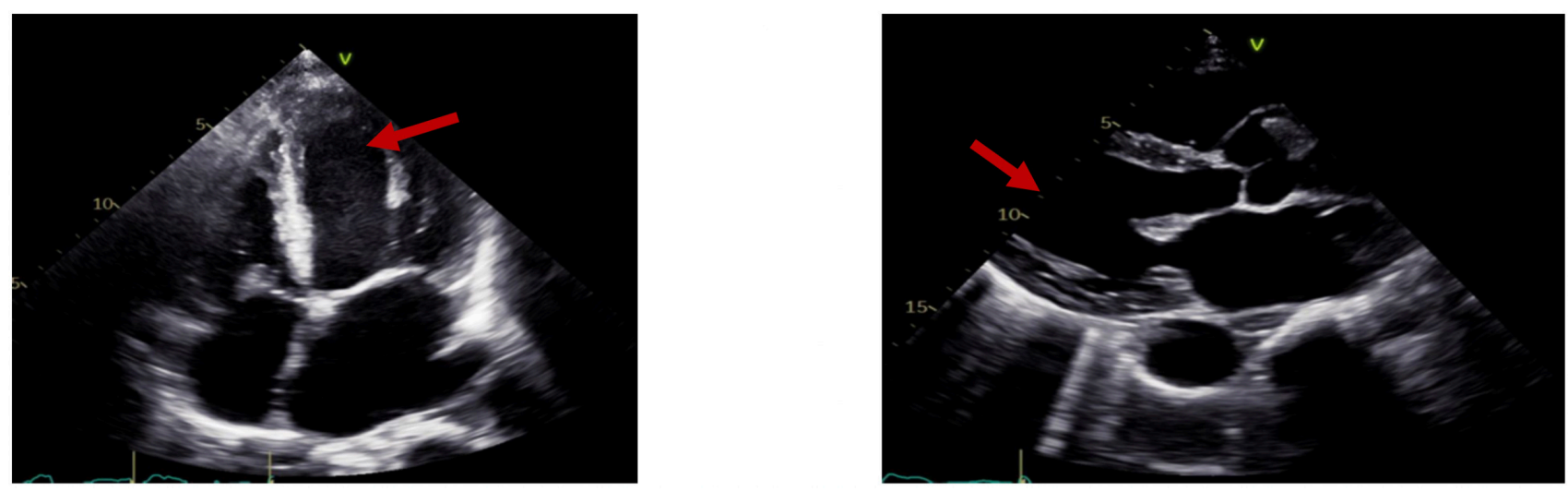

Figure 1. Selected Images from the Echocardiogram of Case 1

Apical four chamber view (left) and parasternal long view (right). Enlarged atria and ventricles with significant dilation of the left and severe decrease in ejection fraction between $10 \%$ to $15 \%$ were the main findings. Red arrows indicate left ventricular 'ballooning.'

moderate tricuspid regurgitation. Her infection was treated with vancomycin and ceftriaxone. To manage her pain and withdrawal symptoms, she was given methadone, $5 \mathrm{mg}$, twice daily and fentanyl for breakthrough pain. Of note, this was not her stated maintenance dose of $60 \mathrm{mg}$ because her methadone clinic could not be contacted. Inpatient valve surgery was planned for when her condition would stabilize.

Twelve days after admission, she became tachypneic and tachycardic with hypoxia. Her troponin level was $0.372 \mathrm{ng} / \mathrm{mL}$, and arterial blood gases revealed acute hypoxemic hypercapnic respiratory failure. Chest imaging revealed worsening multifocal airspace disease with pulmonary edema and small pleural effusions, and EKG demonstrated new T-wave inversions on anterolateral leads. Her condition did not improve despite diuresis and bilevel positive airway pressure treatment, and she became increasingly lethargic. She was upgraded to the ICU where she was treated with bilevel positive airway pressure, but oxycodone and methadone were discontinued. Repeat echocardiogram later that day revealed a further reduction in ejection fraction to less than $20 \%$, with akinesis noted in the $2 / 3-3 / 4$ portions of the distal ventricle. There was moderate right ventricular enlargement, dysfunction, and akinesis (Figure 2). She was diagnosed with TCM with cardiogenic shock and was treated with inotropic agents, including dobutamine and milrinone. Cardiac catheterization was not pursued because her presentation and imaging were highly suggestive of TCM. Morphine treatment was started for pain management. She remained in the ICU for 1 week, where she continued antibiotics, fluid resuscitation, and pressors. She was stepped down to acute care services for continued vancomycin and pain management, as well as resumption of methadone, $5 \mathrm{mg}$. On discharge 1 month later, her ejection fraction had improved mildly to $20 \%$ to $25 \%$ and left ventricular size and wall motion were close to baseline. She was lost to follow-up. 

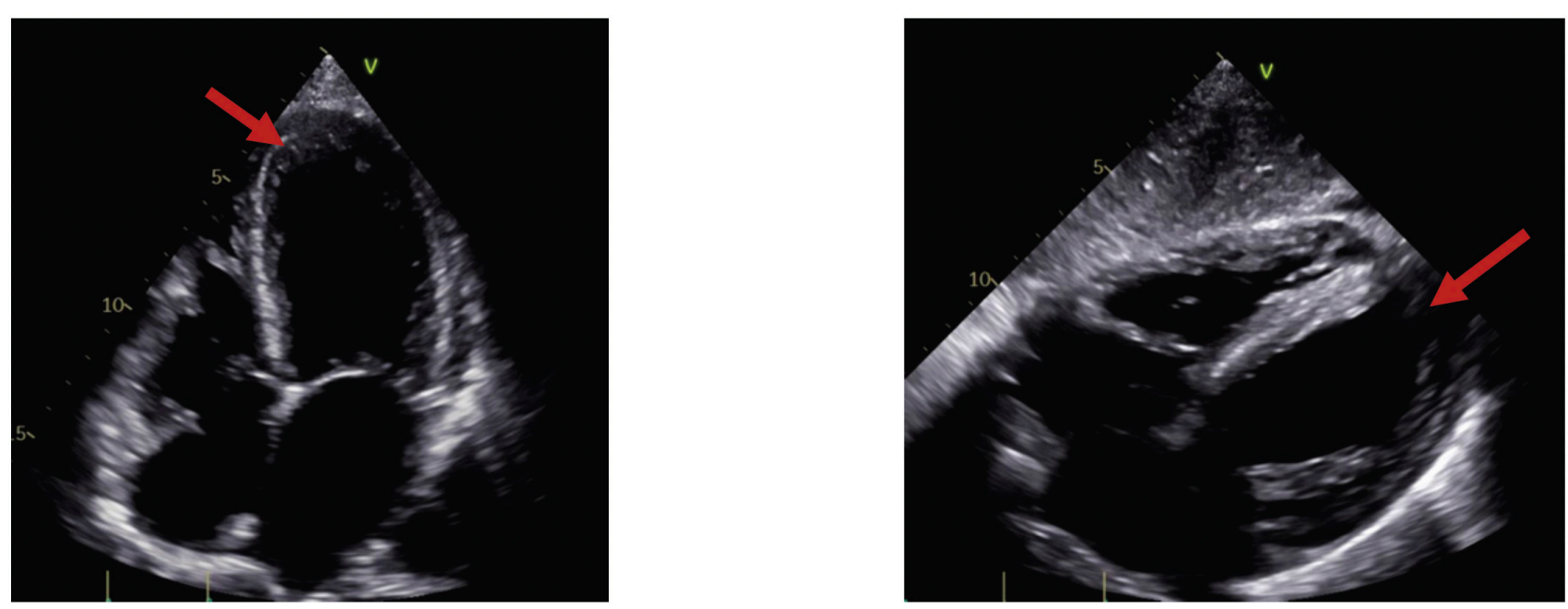

Figure 2. Selected Images from the Echocardiogram of Case 2

Apical four chamber view (left) and subxiphoid view (right). Apical ballooning of the left ventricle is apparent and anterior wall motion was decreased. Ejection fraction was determined to be $20 \%$. Red arrows indicate left ventricular 'ballooning.'

\section{Discussion}

We reported 2 cases of patients potentially experiencing opioid withdrawal who developed TCM during their hospital course. Although the diagnosis was clear in both patients based on these findings, the etiology was uncertain. While the timeline and symptoms of opioid withdrawal for case 1 were more convincing for a direct causal relationship, the TCM pathogenesis of case 2 was confounded by her deteriorating state prior to the diagnosis. Because symptoms of opioid withdrawal could not be assessed, we cannot conclude with confidence that opioid withdrawal was the direct cause of her TCM. The cessation of her opioid maintenance treatment for her first 2 days in the ICU mirrors the opioid-free period of case 1 , which provided enough time for him to develop withdrawal. Especially with case 1's recent presentation in mind, case 2 prompted us to explore the literature to determine whether opioid withdrawal was the primary etiology of her TCM.

TCM is theoretically a result of a hyperadrenergic state, and opioid withdrawal is well-established as an etiology of catecholamine excess and subsequent sympathetic overstimulation. ${ }^{1,5,6}$ To explore this connection, we searched Ovid Medline using the keywords opioid-related disorders or substance withdrawal syndrome and Takotsubo cardiomyopathy. Additionally, Google Scholar was searched for opioid withdrawal cardiomyopathy. Although a systematic review was not identified, 12 total case reports were found (Table 1). ${ }^{8-19}$ 
Table 1. Characteristics of Cases Reporting TCM Associated with Opioid Withdrawal

\begin{tabular}{|c|c|c|c|c|c|c|c|c|c|}
\hline Author & $\begin{array}{l}\text { Patient } \\
\text { age, } y / \text { sex }\end{array}$ & $\begin{array}{l}\text { Country of } \\
\text { publication }\end{array}$ & $\begin{array}{l}\text { Date of } \\
\text { publication }\end{array}$ & Opioid drug & Opioid withdrawal symptoms & $\begin{array}{l}\text { TCM } \\
\text { symptoms }\end{array}$ & $\begin{array}{l}\text { Troponin } \\
\text { (peak)/ST } \\
\text { elevations }\end{array}$ & $\mathrm{EF}$ & Management \\
\hline Rivera et al ${ }^{8}$ & 61/Female & US & 2006 & Oxycodone & $\begin{array}{l}\text { Back pain, nausea, mild respiratory } \\
\text { depression }\end{array}$ & $\begin{array}{l}\text { Dyspnea, } \\
\text { chest pain }\end{array}$ & $\begin{array}{c}+(0.45) /+, \\
\text { precordial } \\
\text { leads }\end{array}$ & $26 \%$ & NSTEMI ${ }^{\mathrm{a}}$ BiPAP, diuretics \\
\hline $\begin{array}{l}\text { Maruyama } \\
\text { et al }\end{array}$ & 2/Female & Japan & 2006 & Buprenorphine & $\begin{array}{l}\text { Perspiration, tachycardia, weight } \\
\text { loss }\end{array}$ & $\begin{array}{l}\text { Hypotension, } \\
\text { tachycardia }\end{array}$ & $-/+$ & NR & $\begin{array}{l}\text { NSTEMla buprenorphine } \\
\text { resumed and weaned slowly }\end{array}$ \\
\hline $\begin{array}{l}\text { Yousuf et } \\
\text { al }{ }^{10}\end{array}$ & 58/Female & US & 2009 & Fentanyl & $\begin{array}{l}\text { Dysphoria, rhinorrhea, diaphoresis, } \\
\text { nausea, vomiting, seizure }\end{array}$ & NR & $\begin{array}{l}+(10.2) /+ \\
\quad \mathrm{V} 2-\mathrm{V} 6\end{array}$ & NR & $\begin{array}{l}\text { NSTEMla pneumonia }{ }^{b} \text { intubation, } \\
\text { fentanyl }\end{array}$ \\
\hline $\begin{array}{l}\text { Lemesle et } \\
\mathrm{al}^{11}\end{array}$ & 44/Male & US & 2010 & Methadone & $\begin{array}{l}\text { Agitation, hallucinations, } \\
\text { hypertension, tachycardia, fever }\end{array}$ & NR & $\begin{array}{l}+(1.99) /+ \\
\text { diffuse }\end{array}$ & $35 \%$ & Midazolam, supportive \\
\hline $\begin{array}{l}\text { Loiberstetter } \\
\text { et al }{ }^{12}\end{array}$ & 56/Female & Germany & 2010 & Unspecified & Unspecified & $\begin{array}{l}\text { Fatigue, } \\
\text { dyspnea, } \\
\text { syncope }\end{array}$ & $\begin{array}{l}+(7.27) /+, \mathrm{II} \\
\text { III and } \mathrm{aVF}\end{array}$ & $25 \%$ & $\begin{array}{l}\text { Heparin and marcumar, } \\
\text { intubation }\end{array}$ \\
\hline Saiful et al ${ }^{13}$ & 60/Male & UK & 2011 & Methadone & Agitated, tachycardia, hypertensive & $\begin{array}{l}\text { Retrosternal } \\
\text { chest } \\
\text { pressure }\end{array}$ & $+(1.68) /+$ & $25 \%$ & Naloxone infusion \\
\hline $\begin{array}{l}\text { Spadotto et } \\
\text { al }^{14}\end{array}$ & 41/Female & Italy & 2013 & Methadone & $\begin{array}{l}\text { Pupillary dilatation, lacrimation and } \\
\text { diarrhea, respiratory depression }\end{array}$ & NR & $+/-$ & $20 \%$ & $\begin{array}{l}\text { Clonidine, furosemide, } \\
\text { dobutamine }\end{array}$ \\
\hline $\begin{array}{l}\text { Revelo et } \\
\mathrm{al}^{15}\end{array}$ & 40/Male & US & 2013 & Methadone & Nausea, vomiting, nervousness & $\begin{array}{l}\text { Palpitations, } \\
\text { tachycardia }\end{array}$ & $+(4.7) /-$ & $<25 \%$ & $\begin{array}{l}\text { Metoprolol, lisinopril, } \\
\text { rosuvastatin, aspirin }\end{array}$ \\
\hline $\begin{array}{l}\text { Sarcon et } \\
\mathrm{al}^{16}\end{array}$ & 60/Female & Switzerland & 2014 & Morphine & $\begin{array}{l}\text { Abdominal discomfort, nausea, } \\
\text { vomiting, chills, diaphoresis }\end{array}$ & Chest pain & $+(21.12) /+$ & $35 \%$ & $\begin{array}{l}\text { Nitroprusside infusion, morphine } \\
\text { resumed and weaned gradually }\end{array}$ \\
\hline Olson et al ${ }^{17}$ & 66/Female & US & 2018 & Oxycodone & Anxiety, agitation, tachycardia & $\begin{array}{l}\text { Mild } \\
\text { respiratory } \\
\text { distress }\end{array}$ & $+(4.42) /-$ & $20-25 \%$ & $\begin{array}{l}\text { Opiates at home dose followed } \\
\text { by methadone }\end{array}$ \\
\hline $\begin{array}{l}\text { Surmaitis et } \\
\mathrm{a}^{18}\end{array}$ & 34/Female & Australia & 2018 & Buprenorphine & $\begin{array}{l}\text { Tachycardic, tachypneic, } \\
\text { diaphoretic, dyspneic }\end{array}$ & Tachycardia & $\begin{array}{l}+(8.7) /+ \\
\text { anterolateral }\end{array}$ & $10 \%$ & Buprenorphine \\
\hline $\begin{array}{l}\text { Keituqwa et } \\
\mathrm{a}^{19}\end{array}$ & 49/Female & Spain & 2019 & Buprenorphine & Diarrhea, abdominal pain` & $\begin{array}{l}\text { Chest pain, } \\
\text { hypotension }\end{array}$ & $+(4.9) /-$ & $38 \%$ & Volume depletion, levosimendan \\
\hline
\end{tabular}

Abbreviations: BiPAP, bilevel positive airway pressure; EF, ejection fraction; NR, not reported; NSTEMI, non-ST elevation myocardial infarction; TCM, Takotsubo cardiomyopathy; UK, United Kingdom

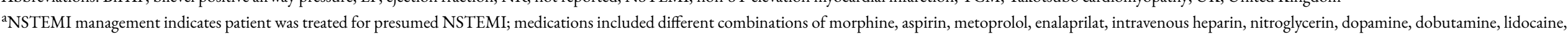
and intravenous eptifitabide.

${ }^{\mathrm{b}}$ Pneumonia management included intravenous vancomycin and ceftriaxone. 
Among the case reports found, the patients were primarily between the ages of 44 and 66 years and female. Five reports were from the US, and the rest were from 7 other countries in 3 different continents. The earliest reported cases were in 2006, 15 years after the first diagnosis of TCM. Most of the patients were taking opioid agonists, including 3 taking buprenorphine (a partial agonist) and 4 taking methadone (a full agonist); 3 patients were using opioids recreationally, and 2 were dependent on oxycodone for pain management. In each case, the patient's symptoms were consistent with opioid withdrawal and subsequent TCM with corroborating diagnostic findings. Although management ranged from presumed non-ST elevation myocardial infarction to supportive care with resumed opioids, all patients survived with resolution within a few weeks. However, most patients did not return to their baseline cardiac function.

Although this is the first literature review specifically on opioid withdrawal complicated by TCM, to our knowledge, other substances have been discussed in this context. Ishida et $\mathrm{al}^{20}$ reported 1 case and reviewed 11 cases of TCM associated with severe alcohol withdrawal. They attributed this connection to a hyperadrenergic state and suggested a lack of routine EKGs or echocardiograms in delirium tremens may be contributing to underdiagnosis of this complication. ${ }^{20}$ There have been international reports of sympatholytic withdrawal from either $\beta$-blockers or $\alpha$-2-agonists leading to TCM; each case concluded a hyperadrenergic state was likely responsible. ${ }^{21-25}$ Two cases of withdrawal from the antispasmodic baclofen and 1 case of antidepressant withdrawal leading to TCM were also reported. ${ }^{26-28}$

\section{Conclusions}

TCM may prove to be a rare complication of opioid withdrawal. We presented 2 cases that contribute to the scant but growing literature supporting this connection. With the limited data on this subject, we cannot conclude whether there are risk factors for TCM development, although most reported cases were women older than 40 years. We also cannot make strong conclusions regarding proper management, other than resuming and gradually weaning opioids while providing supportive care. Further quantitative research, such as a cohort study, is needed to establish a true association and change clinical practice. Depending on the findings, emergency medicine and outpatient practitioners may need to update diagnostic algorithms for cardiac injuries in patients undergoing opioid withdrawal. This could potentially lead to saved time and resources in treating this population.

Fortunately, outcomes for the patients we presented here were quite positive. In each case, the patient survived with moderate reduction in their baseline cardiac function. TCM is still not completely understood, but cases of antiadrenergic substance withdrawal leading to TCM support the theory that a hyperadrenergic state leads to the cardiac dysfunction and largely reversible anatomical abnormalities seen in this condition. 


\section{REFERENCES}

1. Amin HZ, Amin LZ, Pradipta A. Takotsubo cardiomyopathy: a brief review. J Med Life. 2020;13(1):3-7.

2. Dote K, Sato H, Tateishi H, Uchida T, Ishihara M. [Myocardial stunning due to simultaneous multivessel coronary spasms: a review of 5 cases]. In Japanese. J Cardiol. 1991;21(2):203-214.

3. Prasad A, Lerman A, Rihal CS. Apical ballooning syndrome (Tako-Tsubo or stress cardiomyopathy): a mimic of acute myocardial infarction. Am Heart J. 2008;155(3):408-417. doi:10.1016/j.ahj.2007.11.008

4. Roshanzamir S, Showkathali R. Takotsubo cardiomyopathy: a short review. Curr Cardiol Rev. 2013;9(3):191-196. doi:10.2174/1573403x11309030003

5. Ahtee L, Attila LM. Cerebral monoamine neurotransmitters in opioid withdrawal and dependence. Med Biol. 1987;65(2-3):113-119.

6. Aghajanian GK. Central noradrenergic neurons: a locus for the functional interplay between alpha-2 adrenoceptors and opiate receptors. J Clin Psychiatry. 1982;43(6, pt 2):20-24.

7. Rehman SU, Maqsood MH, Bajwa H, Tameez Ud Din A, Malik MN. Clinical efficacy and safety profile of lofexidine hydrochloride in treating opioid withdrawal symptoms: a review of literature. Cureus. 2019;11(6):e4827. doi:10.7759/cureus. 4827

8. Rivera JM, Locketz AJ, Fritz KD, et al. "Broken heart syndrome” after separation (from OxyContin). Mayo Clinic Proc. 2006;81(6):825-828.

9. Maruyama S, Nomura Y, Fukushige T, et al. Suspected Takotsubo cardiomyopathy caused by withdrawal of bupirenorphine in a child. Circ J. 2006;70(4):509-511. doi:10.1253/circj.70.509 10. Yousuf MA, Adjei S, Kinder B. A 58-year-old woman with ST-segment elevation, seizures, and altered mental status in the setting of opiate withdrawal. Chest. 2009;135(4):1098-1101.

doi:10.1378/chest.08-2164

11. Lemesle F, Lemesle F, Nicola W, Pierre Jonville-Béra A. First case of stress cardiomyopathy as a result of methadone withdrawal secondary to drug-drug interaction. Am J Emerg Med.

2010;28(3):387.e5-387.e6. doi:10.1016/j.ajem.2009.07.007

12. Loiberstetter A, Wöhrl B, Sollfrank R, Pfefferkorn T. Bilaterale media- und posteriorinfarkte bei Takotsubo-kardiomyopathie [Bilateral medial and posterior infarction in Takotsubo cardiomyopathy]. In German. Nervenarzt. 2010;81(4):435-436. doi:10.1007/s00115-010-2929-4 13. Saiful FB, Lafferty J, Jun CH, et al. Takotsubo cardiomyopathy due to iatrogenic methadone withdrawal. Rev Cardiovasc Med. 2011;12(3):164-167.

14. Spadotto V, Zorzi A, Elmaghawry M, Meggiolaro M, Pittoni GM. Heart failure due to 'stress cardiomyopathy': a severe manifestation of the opioid withdrawal syndrome. Eur Heart J Acute Cardiovasc Care. 2013;2(1):84-87. doi:10.1177/2048872612474923

15. Revelo AE, Pallavi R, Espana-Schmidt C, Visco F, Pekler G, Mushiyev S. 'Stoned' people can get stunned myocardium: a case of heroin withdrawal precipitating Tako-Tsubo cardiomyopathy. Int J Cardiol. 2013;168(3):e96-e98. doi:10.1016/j.ijcard.2013.07.120

16. Sarcon A, Ghadri JR, Wong G, Lüscher TF, Templin C, Amsterdam E. Takotsubo cardiomyopathy associated with opiate withdrawal. QJM. 2014;107(4):301-302. doi:10.1093/ qjmed/hct 219

17. Olson PC, Agarwal V, Lafferty JC, Bekheit S. Takotsubo cardiomyopathy precipitated by opiate withdrawal. Heart Lung. 2018;47(1):73-75. doi:10.1016/j.hrtlng.2017.10.001 
18. Surmaitis RM, Khalid MM, Vearrier D, Greenberg MI. Takotsubo cardiomyopathy associated with buprenorphine precipitated withdrawal. Clin Toxicol (Phila). 2018;56(9):863-864.

doi:10.1080/15563650.2018.1437921

19. Keituqwa Yáñez I, Nicolás Franco S, Arcís Conesa A. Valoración ecocardiográfica integral en un caso de miocardiopatía de takotsubo por privación de opiáceos. Med Intensiva.

2019;43(9):591-592. doi:10.1016/j.medin.2019.02.006

20. Ishida T, Uchida H, Miyazaki K, et al. A possible role of Takotsubo cardiomyopathy in ventricular fibrillation during delirium tremens: a case report and literature review. Psychosomatics. 2018;59(3):293-297. doi:10.1016/j.psym.2017.11.008

21. Lee HM, Ruggoo V, Graudins A. Intrathecal clonidine pump failure causing acute withdrawal syndrome with "stress-induced" cardiomyopathy.J Med Toxicol. 2016;12(1):134-138. doi:10.1007/ $\underline{\text { s13181-015-0505-9 }}$

22. Mörkl S, Bengesser SA, Schöggl H, Bayer D, Kapfhammer HP. Tizanidin-absetzsymptome bei stress-kardiomyopathie [Tizanidine withdrawal symptoms in stress cardiomyopathy]. In German. Fortschr Neurol Psychiatr. 2015;83(3):170-173.

23. Bezgin T, Elveran A, Doğan C, Çanga Y, Karagöz A, Esen AM. Takotsubo cardiomyopathy after bisoprolol withdrawal and open appendectomy. Herz. 2014;39(3):405-411. doi:10.1007/ $\underline{\mathrm{s} 00059-013-3841-\mathrm{z}}$

24. Tomcsányi J, Jávor K, Arabadzisz H, Zsoldos A, Wagner V, Sármán B. Béta-blokkoló-megvonás okozta takotsubo cardiomyopathia [Takotsubo cardiomyopathy: a novel beta-adrenergic blocker withdrawal syndrome]. In Hungarian. Orv Hetil. 2013;154(7):267-271. doi:10.1556/ oh.2013.29545

25. Jefic D, Koul D, Boguszewski A, Martini W. Transient left ventricular apical ballooning syndrome caused by abrupt metoprolol withdrawal. Int J Cardiol. 2008;131(1):e35-e37. doi:10.1016/j.ijcard.2007.07.060

26. Kireyev D, Poh KK. Reversible electrocardiogram changes and cardiomyopathy secondary to baclofen withdrawal syndrome. Am Heart HospJ. 2010;8(1):52-54. doi:10.15420/ahhj.2010.8.1.52 27. Levy J, De Brier G, Hugeron C, Lansaman T, Bensmail D. Takotsubo cardiomyopathy as a reversible complication of intrathecal baclofen withdrawal. Ann Phys Rebabil Med. 2016;59(5-6):340-342. doi:10.1016/j.rehab.2016.07.384

28. Marabotti C, Venturini E, Marabotti A, Pingitore A. Delayed multifocal recurrent stressinduced cardiomyopathy after antidepressants withdrawal. Heart Lung. 2014;43(3):225-230. doi:10.1016/j.hrtlng.2014.03.003 